\title{
Improvement Design for The Effectiveness of Tracer Studies Process in Bandung's Private University
}

\author{
Mochamad Fabian Redhatama, Wiyono Sutari, and Heriyono Lalu \\ School of Industrial and System Engineering, Telkom University, Bandung \\ e-mail: fabianredhatama@telkomuniversity.ac.id
}

\begin{abstract}
A concrete step to obtain information is to have a good management information system. For universities, one of the most important information is about alumni or graduate's feedback. However, the actual management information system in several Bandung's private university cannot provide the information desired by the department and the tracer studies response rate is far from good. Which means the tracer study process needs to be re-engineered. Thus, this research aims to redesign the business processes by analyzing the "As-Is". This research found that a good tracer study system needs to build a good relationship with the alumni. So that, this research proposes the key success factor for the effectiveness of tracer studies in Bandung's private universities. Since the response rate is one of the key indicators of tracer studies, supposed that in order to increasing the response rate. The universities should create good relationships with the alumni since they were in sophomore year with their guardian lecturer and thesis' promotor. Thus, this reengineered process should be useful in order to increase the tracer studies process productivity that measured by response rate to supports national data collection and comparisons for better education curriculum evaluations.
\end{abstract}

Keywords-Business Process Management, Key Success Factors, Tracer Study, Reengineering, BPM Lifecycle.

\section{INTRODUCTION}

A CONCRETE step to get information is to have a good management information system. Management information systems can provide stakeholders who are in the system to more easily access information for certain interests. For universities, one of the most important information is information about alumni or graduate feedback. In general, this is given the term tracer study. Tracer study is a research process for graduates of higher education providers to find out whether the graduates produced have good competence and are relevant to the needs of the workforce [1, p. 12].

As one of the tertiary institutions organizing education in Indonesia, the Ministry of Research, Technology and Higher Education (Kemenristekdikti) in order to obtain accurate National data on the situation of higher education relations and the world of work requires all registered universities to conduct tracer studies in accordance with implementation guidelines tracer study No. 313 / B / SE / 2016 is equipped with tracer study guidelines originating from accreditation forms of study programs (IAPS) and accreditation of higher education institutions (AIPT).
Career Development Centre (CDC) Division is assigned by all Bandung's private universities to meeting the need of specific requirements to obtain all graduates data nationally.

This division also need to meet the needs of obtaining information from alumni related to key indicators in the form of learning outcomes and student outcomes that are designed through the curriculum of each study program. The basis of curriculum design is obtained from knowing the profile of graduates, core competencies, and supporting competencies in accordance with the vision and mission of each study program that can only be obtained by tracer study. 3 private universities only obtain average response rate as seen in Figure 1 . With that response INDOTRACE (Indonesian Association Tracer Study) assume that above $30 \%$ response rate is well enough [2]. One of its source comes from the level of alumni ignorance which can be measured by the gap between the gross response and the real response tracer study which continues to increase every year in Figure 2. Because, the real response of this tracer study illustrates the number of alumni who filled out this tracer study survey independently. Then the gap between gross response and real response is also called via call response. Via call response is an incidental action carried out by the CDC Tracer Study Unit to achieve the gross response rate target to meet the CDC quality objectives, namely by making massive contact with alumni and asking directly related to the tracer study questions via voice calls. The voice call can spend an average of 30 minutes per graduate. That causes the process costs to increase every year. Meanwhile, according to tracer study system requirements [3] target should be all graduates population to assure the data compilation and comparison nationally. Which means the tracer study process needs to be re-engineered. Thus, this research aims to identified process weaknesses that caused the low response rate and design new process to solve the problems.

\section{LITERATURE REVIEW}

Management Information SystemManagement Information System is a flow processing procedure based on computer data that is integrated with other procedures to provide information in a timely and effective way to support decision making and other management functions. Information systems are an integrated set of components for collecting, storing, and processing data and for sending information, cards and digital 


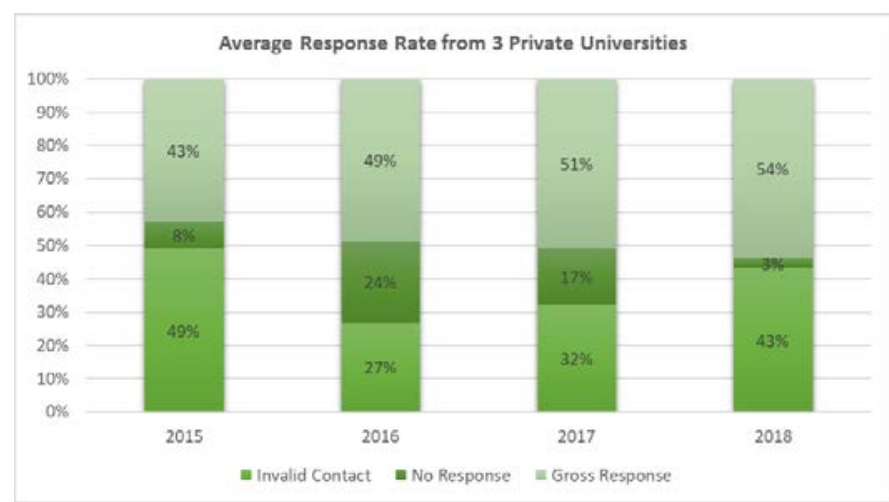

Figure 1. Average Response Rate from 3 Private Universities.

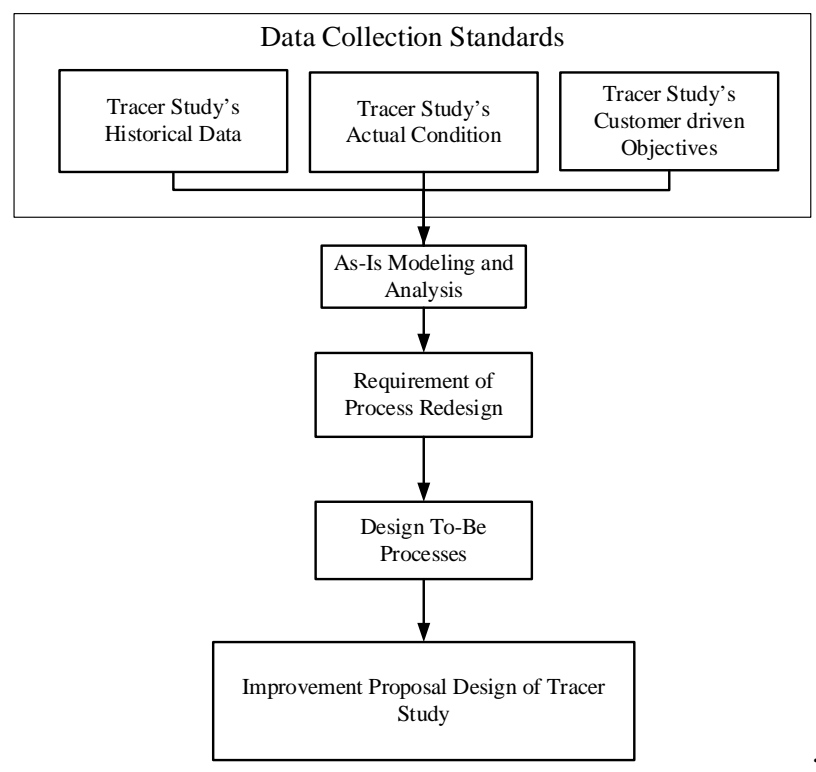

Figure 3. Research Methodology.

products in the form of dynamic areas or areas for monitoring change, perhaps the most important driving force caused by the development of functional and related computers with information [4, p. 19].

\section{A. Business Process}

Business process is a collection of interrelated activities, started in response to trigger events, which achieve specific and different results for customers and other stakeholders of the process [5, p. 56]. In general, business processes can assist organizations in managing operations in such a way that they can produce outputs that provide added value. Business processes can coordinate some of its elements such as people, resources, systems, and work [5, p. 62].

\section{B. Business Process Management}

Business Process Management or commonly known as Business Process Management (BPM) is one methodology carried out by an institution treating its business processes as a valuable asset. If well designed and efficient, this BPM can help an institution improve the quality of core activities and support activities in it. BPM has the aim to manage well the changes that

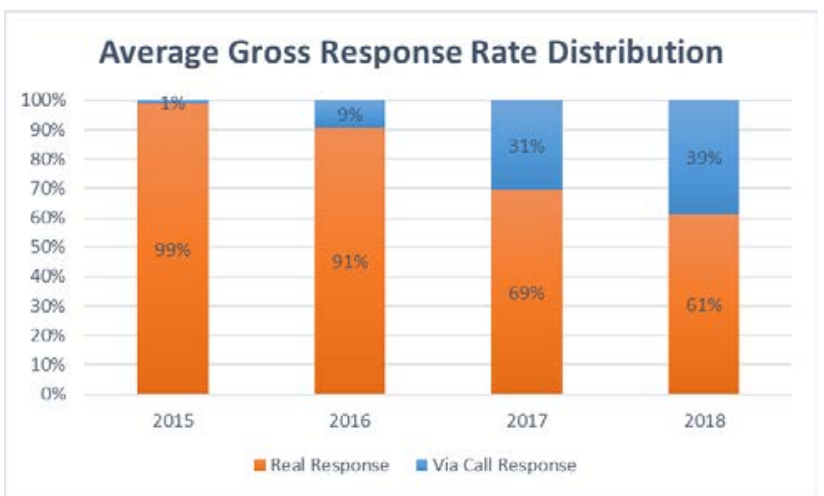

Figure 2. Average Gross Response Rate Distribution.

occur in various aspects ranging from aspects of technological development, human psychology, and so on so that the process that is built can still have a stable quality and even increase effectively and efficiently. Business process management (BPM) is a scientific discipline to identify, execute, document, measure, monitor, and supervise both automated and nonautomated business processes to achieve consistency towards an objective [6, p. 24]. BPM currently combines Business Process Reengineering methods and techniques with Business Process Management Suite (BPMS) automation capabilities to achieve radical transformation in a business [6, p. 371].

\section{Business Process Modeling}

Business Process Modeling is a means to represent business activities, information flow and decision logic in an organization's business processes to provide information to people who read the model or people who make it [7, p. 9]. Business Process Modeling is divided into 3 types including; Executive or Strategic processes and creative or collaborative processes where these processes are described do not take the form of steps but rather the requirements needed for analysis.

Transactional processes that tend to be in the form of repetitive work so that very specific workflow modeling is needed [5, p. 56].

\section{Reference Model}

The Reference Model is an abstract framework created for understanding significant relationships between entities and their environment. In addition, this reference model is used for the development of consistent standards or specifications that can support the environment. The reference model is based on a small and simple overview of a concept so that it can be used as a basis for education and explain standards to non-specialists. APQC PCF, VRM, and eTOM can be an option for reference when you want to model something [8, p. 7].

\section{RESEARCH METHODOLOGY}

\section{A. Data Collection Standards}

In designing this proposed process, it must begin by designing the business process in accordance with the real 
International Conference on Business and Engineering Management 2020 (IConBEM 2020)

February $1^{\text {st }}$ 2020, Institut Teknologi Sepuluh Nopember, Surabaya, Indonesia system or actual. First, historical data is needed to determine the behavior of an actual process. Second, Actual conditions to find out the whole process that focuses on Private University Tracer Study Unit. Finally, Customer Driven Objectives, which are the outcomes of the tracer study expected by the customer. Customers in this study are lecturers and students. As a source of design, Customer driven objectives also use benchmark reference model data and literature studies from researches that focus on making the data collection process of alumni better.

\section{B. “As-Is” Modelling and Analysis}

This process begins with designing the actual business process by mapping the problem using historical data and actual conditions to get some insights on weaknesses and their impact consequences [9].

\section{Requirement of Process Redesign}

This process gives us the guides to redesign what this redesign wants to achieved. Mostly, this redesign are based on the "As-Is" Problem Mapping, process objectives, customer driven objectives, and system requirements.

\section{Design “To-Be” Processes}

This process is the reengineering process which starts determining the input (guides, data requirements, enablers), process structure (Redesigned Organization Structure, RASCI (Responsible, Accountable, Supports, Consulted, and Informed) Model based on [10], and Process Performances Measurement) based on [6], and output (key success factor of the output and outcome process surveys). Since this case is for tracer studies. The improvement proposal could be useful for further research as to be implemented for better industry.

\section{RESULT AND DISCUSSION}

\section{A. “As-Is” Modelling and Analysis}

This tracer study process is generalized by analyse all private universities actual processes. Figure 4-5 are the summaries of the process that drawn in BPMN 2.0 using iGrafx [11].

According to several private universities tracer study processes, they have a common mistaken because they benchmarking each other for tracer study implementations. Table 1. defines several common mistakes that runs in several private universities. Which makes them have similar result of response rate.

For better tracer study processes, it is required to have reference model from framework or literature studies. For the process design framework we can use American Productivity and Quality Center Process Classification Framework for Education (APQC PCF) [12] that presents in Table 2. and for literature studies in order to do the construct idea validity presents in Table 3.

\section{B. Business Process Reengineering Requirements}

After conducted "As-Is” Modeling and Analysis, now we have the requirements for redesigning this process. There are 4 requirements, which are:

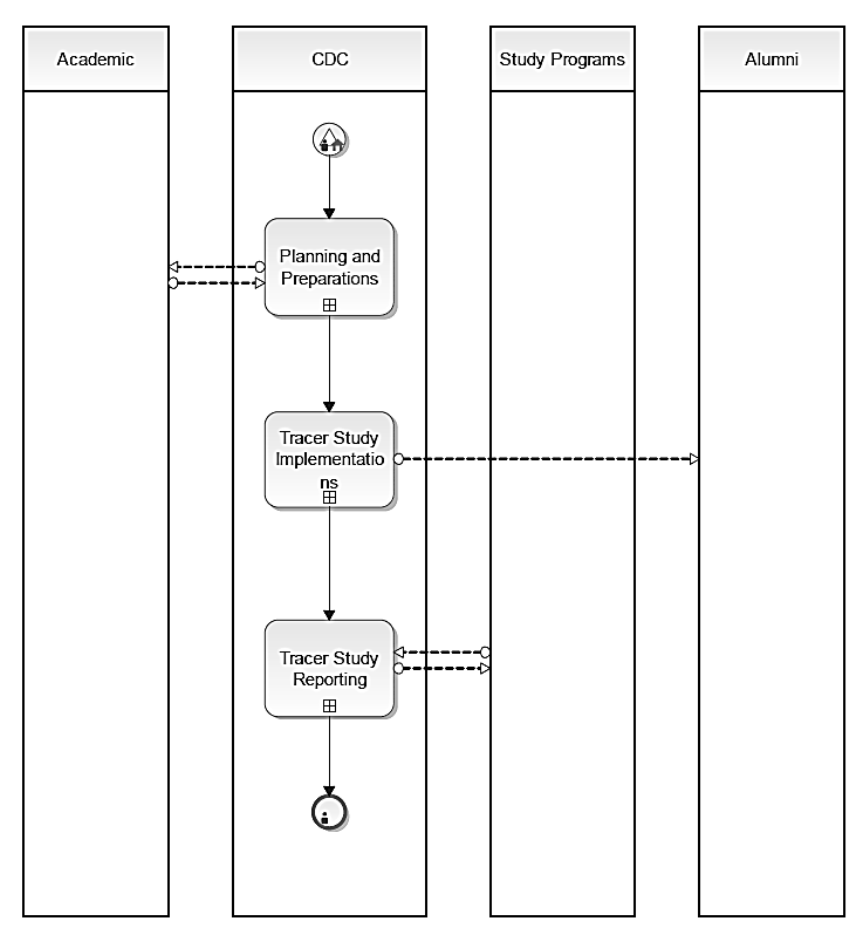

Figure 4. Tracer Study Common Actual Processes.

1. Reengineered Process should be delivering the process objectives (Knowing the Condition of Graduates, Knowing Educational Outcomes, and as an Educational / Curriculum Evaluation Information). [1]

2. Reengineered Process should follows System's Requirement [3]

3. Reengineered Process should follow APQC PCF Reference Model 5.0 based on Table 2.

4. Reengineered Process should be solving As-Is Problem Mapping Weaknesses based on Table 1.

\section{Design “To-Be" Process}

The process design method comes from determining the input, process structures, output and its outcomes [18, p. 77] that defines in Figure 6. and supported by its enablers [5, p. 69] that defines in Figure 7.

This reengineering process starts from determining the input (guides, data requirements, enablers) which defines in Table 5., process structure (Redesigned Organization Structure in Figure 8., RASCI Model in Table 6-7., and Process Performances Measurement in Table 8-9.), and output (key success factor of the output and outcome process surveys) which defines in Table 4.

After redesigning the process and documented using IDEF [19] becoming like Figure 9., the key success factor is considered to have optimum and effective process performance. So that, the critical success factor of this process comes from a good relationship and communications with the alumni. Thus, Table 10. will defines the Alumni Communication Success Level Measurement. 

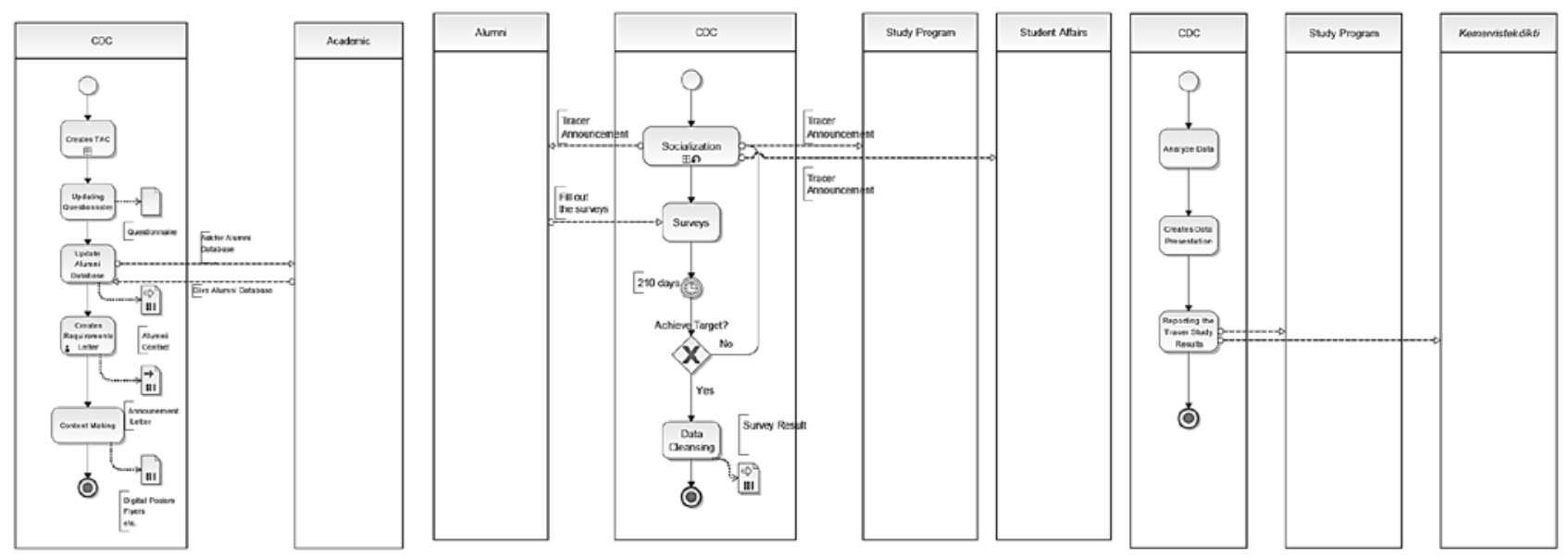

Figure 5. Tracer Study Detailed Process (Planning, Implementation and Reporting).

Table 1.

“As-Is” Problem Mapping

\begin{tabular}{lllcl}
\hline \hline \multicolumn{1}{c}{ Process } & \multicolumn{3}{c}{ Problem Identification } \\
\hline Planning & and & 1. & Bad communication with \\
Preparations & & study program representation \\
& 2. & Questionnaire to generics \\
& 3. & Alumni contact not up-to-date
\end{tabular}

Tracer Study Unwell-known surveyor by the alumni Implementation

Tracer Study

Report Reports were only made for Kemenristekdikti without considering study program as the main purpose of tracer study were conducted

\section{Consequences}

$1 . \quad$ Study program representation does not feel this is matter for them anymore

2. Alumni feedback not really useful for curriculum evaluation or accreditations

3. Invalid alumni contact can caused low response rate

Alumni refuses to give information regarding to tracer study questionnaire requirements

Study program representation having a trust issue to CDC Division. The process not value added for the study program as the process customer
Table 2.

Reference Model APQC PCF For Education 5.0 [12]

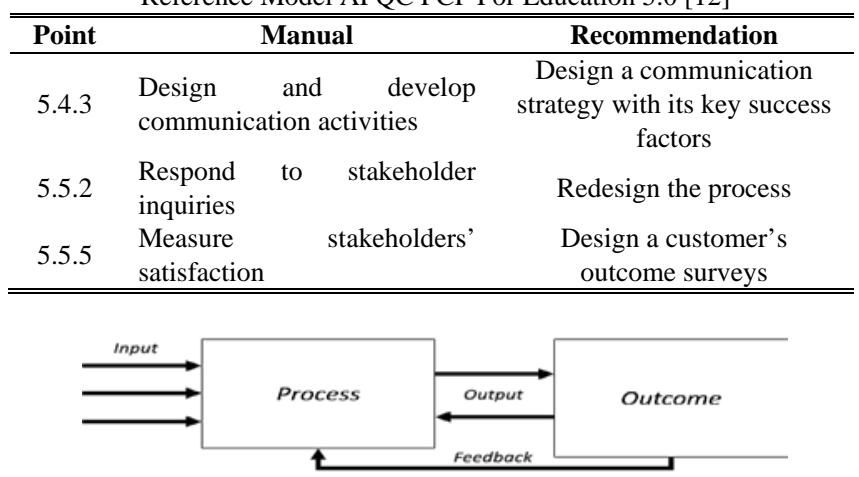

Figure 6. Process Design Structures [18, p. 77].

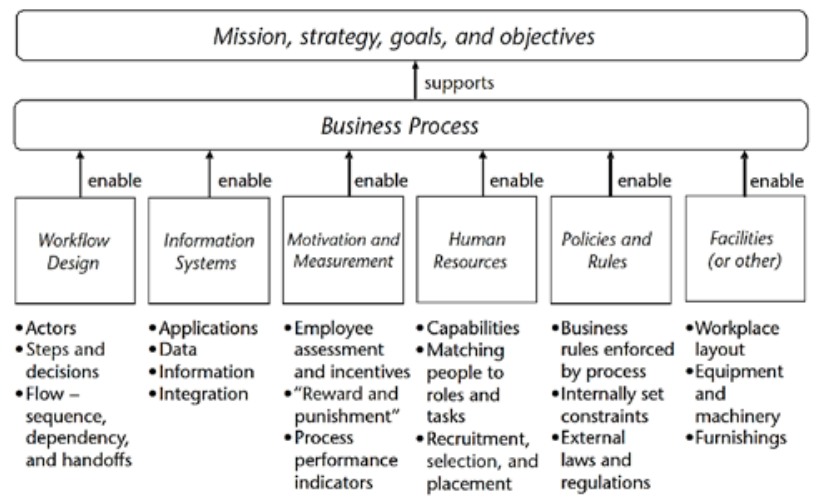

Figure 7. Business Process Six Enablers [5, p. 69].
Table 3.

Construct Validity From Literature Studies

\begin{tabular}{cc}
\hline $\begin{array}{c}\text { Refere } \\
\text { nces }\end{array}$ & \multicolumn{1}{c}{ Research Title } \\
\hline & $\begin{array}{l}\text { Tracer Study System Portal- } \\
\text { Based Social Network To } \\
\text { Optimize Data Collection On } \\
\text { Higher Education Graduates }\end{array}$ \\
\end{tabular}

Alumni Loyalty Drivers In Higher Education

An Integrative Model Of Alumni Loyalty-An Empirical Validation Among Graduates From German And Russian Universities

E-Tracer Study Evaluation [16] Using Hot (HumanOrganization- Technology)

Pros \& Cons of Target Respondent: Between Cohort And Entry Of Cohort

\section{Recommendation Reengineering Planning and Preparations Process}

Reengineering Tracer Study Implementation Process Reengineering Tracer Study Reporting Process

\author{
Discussion \\ Researchers designs tracer \\ study portal look-a-like social \\ media. The researchers \\ believes that with this idea the \\ tracer study data collection will \\ be more optimal \\ Researchers proven that alumni \\ loyalty drivers are comes from \\ several things that builds from \\ sophomore year. \\ Researchers does the structural \\ equation modeling as the \\ empirical validation on the idea \\ of alumni loyalty. Most of \\ them comes from their \\ memorize all of it since they \\ were in sophomore year. \\ The researcher designs a model \\ of e-tracer study usefulness test \\ in his campus. It proves that \\ $79 \%$ feels more confident if \\ tracer study surveys conducted \\ online
}

The researchers shown the pros \& cons on target respondent on cohort and entry cohort. 
Table 4.

Process Output

\begin{tabular}{lll}
\hline \hline No & Types & What \\
\hline 1 & Data & The Tracer Study Report complies with the requirements of the Kemenristekdikti No. system. 313 / B / SE / 2016, Tracer Study Objectives, \\
\hline \hline
\end{tabular}

Table 5.

Process Input

\begin{tabular}{|c|c|c|c|}
\hline No & Types & What & \\
\hline \multirow[t]{2}{*}{1} & Data & Alumni & atabase \\
\hline & & 1. & Tracer Study Letter (Message) \\
\hline \multirow{4}{*}{2} & Funt Triqua & 2. & Tracer Study Timeline (Timer) \\
\hline & Event Irigger & 3. & Task Notification from Information Systems Application (Signal) \\
\hline & & 4. & Undeliverable process (Error) \\
\hline & & 1. & Workflow Design (Cross Functional flow-chart BPMN) \\
\hline \multirow[t]{4}{*}{3} & Enablers & 2. & Required Resources with its roles, functions, authorities, and responsibilities (RASCI Model) \\
\hline & & 3. & Tracer Study Information Systems Application \\
\hline & & 1. & Rector's Decree (Regarding the involvement of Guardian Lecturers / Thesis's Promotors to become Surveyors as stipulate \\
\hline & & 2. & Faculty Management Contract (Tracer Study Achievement Target) made for surveyor’s incentives \\
\hline \multirow{4}{*}{4} & Guides & 3. & System requirements in accordance with Circular of Menristekdikti No. 313 / B / SE / 2016 \\
\hline & Guines & 4. & Tracer Study Objectives (Knowing the Condition of Graduates, Knowing Educational Outcomes, and as an Educational / \\
\hline & & 5. & APQC PCF Based on Table 2. \\
\hline & & 6. & Customer Driven Objectives obtained from the Study Program Satisfaction Survey as a Customer Process and Alumni Sat \\
\hline
\end{tabular}

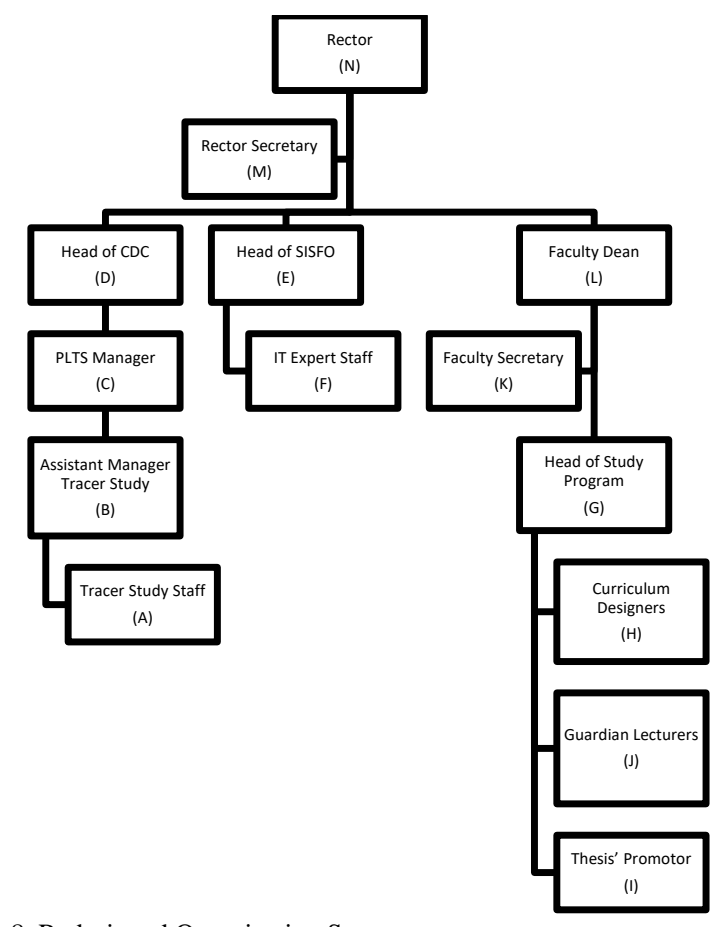

Figure 8. Redesigned Organization Structure.

\section{CONCLUSION}

The following are the conclusions drawn from the results of the design of the improvement of the private university tracer study process. The proposed Tracer Study process involves new actors / resources in it, namely: Thesis' Promotor and Guardian Lecturers who are appointed as surveyors because they have a strong relationship bond compared to surveyors in actual conditions, a joint meeting agenda with study program to get better insight of process requirements, and facilitate stakeholders to obtain information and oversee the process of

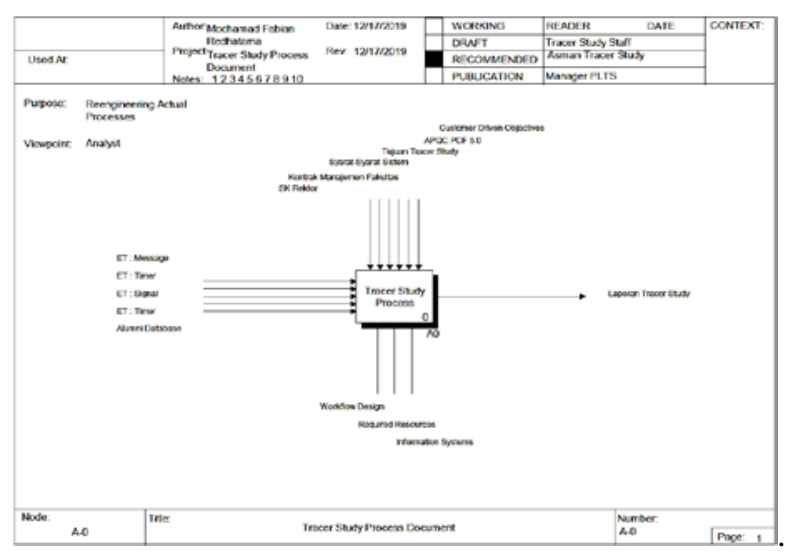

Figure 9. Improvement Design Proposal of Tracer Study.

tracer study with a dashboard feature with all kinds of usefulness for among stakeholders. These improvement could increase process effectiveness.

\section{REFERENCES}

[1] H. Schomburg, "Handbook for Tracer Studies," Cent. Res. High. Educ. Work. Univ. Kassel, 2016.

[2] H. S. Soegoto, R. Wahdiniwaty, L. Warlina, and A. Heryandi, "E-tracer study implementation of Indonesia Computer University alumni,” vol. 6, no. May, pp. 38-46, 2018.

[3] Kemenristekdikti, "TENTANG PELAKSANAAN TRACER STUDY TINGKAT PERGURUAN TINGGI,” 2016.

[4] A. Berisha - Shaqiri, "Management Information System and DecisionMaking,” Acad. J. Interdiscip. Stud., no. July 2014, 2014.

[5] A. Sharp, Workflow Modeling: Tools for Process Improvement and Applications Development 2nd Edition. 2011.

[6] Association of Business Process Management Professional, Guide to the business process management common body of knowledge (BPM CBOK®): АВPMP BPM СBOK®-[version 3.0-third release]. 2013.

[7] S. Nurcan, "Business Process Modelling and Flexibility," Enterp. Interoperability II, pp. 111-114, 2007.

[8] A. Grigoriu, "A Comparison of Common Business Modeling Approaches to GODS Generic Business Architecture,” BPTrends, no. March, 2011.

[9] M. Dumas, M. La Rosa, J. Mendling, and H. A. Reijers, Fundamentals of 
Table 7.

Tracer Study Cross function flow-Process Lists

\begin{tabular}{cl}
\hline \hline No & \multicolumn{1}{c}{ Tracer Study Workflow } \\
\hline 1 & Make Memos to prepare Tracer Study \\
2 & Make a Rector's Decree \\
3 & Preparing a Tracer Study System \\
4 & Updating the Faculty Management Contract \\
5 & Application Socialization and Alumni Database Update \\
6 & Collecting Active Student Contact Data \\
7 & Updating Alumni Contact Data \\
8 & Give an invitation Memo to the Curriculum Development Team \\
9 & Make Memos for Each Study Program to prepare data requirements for curriculum evaluation \\
10 & Internal Meeting of the Curriculum Development Team \\
11 & Joint Meeting of CDC and Study Programs \\
12 & Setting Assignment, Performance Target and Questionnaire in the Application \\
13 & Make an announcement letter to fill the Tracer Study surveys \\
14 & Entry Cohort Surveys \\
15 & Exit Cohort Surveys \\
16 & Process Monitoring \\
17 & Data Presentation \\
\hline \hline
\end{tabular}

Table 8.

Process Performance Measures

\begin{tabular}{|c|c|c|c|}
\hline "Objectives & Performance Indicator & Calculation & "Measurement Frequency \\
\hline \multirow[b]{2}{*}{ Contact Data Collection } & Collected Alumni Contact & $A=\frac{A c}{N I} \times 100 \%$ & Per year \\
\hline & Collected Active Student Contact & $B=\frac{B c}{N B} \times 100 \%$ & Per year \\
\hline \multirow{2}{*}{ Contact Data Validation } & Number of Valid Alumni Contact & $A x=\frac{A x C}{N A x} \times 100 \%$ & Per year \\
\hline & Number of Valid Active Student Contact & $B x=\frac{B x c}{N B x} \times 100 \%$ & Per year \\
\hline \multirow{3}{*}{ Data Collection Tracer Study } & Response Rate & $R=\frac{r}{N_{n}} x 100 \%$ & Per period \\
\hline & Surveyor Productivity & $S P=\frac{r P}{N t} \times 100 \%$ & Per month in period \\
\hline & Unproductive Process & $E=\frac{e}{T} x 100 \%$ & Per period \\
\hline Process Controlling & Delivered Socialization to Alumni & $D S=\frac{d}{N_{L}} x 100 \%$ & Per period \\
\hline
\end{tabular}

Table 9.

Alumni Communication Success Level Measurement

\begin{tabular}{|c|c|c|}
\hline "Level & Name & Average Percentages of Objectives \\
\hline 1 & Uncontrolled Communication & $0-20 \%$ \\
\hline 2 & Relatively Controlled Communication & $21-40 \%$ \\
\hline 3 & Controlled Level Communication & $41-60 \%$ \\
\hline 4 & Conservatively Improving Communication & $61-80 \%$ \\
\hline 5 & Innovative Communication & $81-99 \%$ \\
\hline
\end{tabular}

Business Process Management. 2013.[10] Project Management Institute, A Guide to the Project Management Body of Knowledge (PMBOK® Guide)-Sixth Edition, vol. 44, no. 3. 2017.

[11] iGrafx, "Process Map vs. Process Model," iGrafx, 2015. .

[12] APQC, PROCESS CLASSIFICATION FRAMEWORK FOR EDUCATION. 2007.

[13] F. Marisa et al., "Tracer Study System Portal-Based Social Network To Optimize Data Collection on Higher Education Graduates,” Pros. Int. Conf. Inf. Technol. Bus., pp. 19-24, 2016.

[14] I. Snijders, L. Wijnia, R. M. J. P. Rikers, and S. M. M. Loyens, "Alumni loyalty drivers in higher education,” Soc. Psychol. Educ., vol. 22, no. 3, pp. 607-627, 2019.

[15] L. Iskhakova, A. Hilbert, and S. Hoffmann, “An Integrative Model of
Alumni Loyalty—an Empirical Validation Among Graduates From German and Russian Universities," J. Nonprofit Public Sect. Mark., vol. 28, no. 2, pp. 129-163, 2016.

[16] R. Akbar, "Evaluasi e- Tracer Study menggunakan HOT ( HumanOrganization- Technology ) Fit Model,” J. JTIK (Jurnal Teknol. Inf. dan Komunikasi), vol. 3, no. 2, 2019.

[17] A. D. A, B. S. Budi, S. Mihradi, and B. Yuliarto, "Pros \& Cons of Target Responden : Between Cohort and Entry of Cohort ( Case Study in Itb )," 2015.

[18] A. R. Tenner and I. J. DeToro, Process Redesign: The Implementation Guide for Managers. Addison-Wesley Publishing Company., 2000.

[19] Brian, "Introduction to IDEF0/3 for Business Process Modelling," no. November, pp. 1-14, 2013. 